\title{
CONSTRUCTING POVERTY RANKINGS FOR STATE SUBREGIONS: A CASE STUDY OF NORTH CAROLINA
}

\author{
John A. Bishop and Lester A. Zeager*
}

\begin{abstract}
My own main concern - and, as I perceive it, the concern of the international development community - is with the alleviation of absolute economic misery. Given this judgment, it does not seem desirable to use relative inequality indexes to measure changing income distribution. Rather, it is more appropriate to use absolute income and poverty measures ... [Fields (1980, p. 182)]

Opposing the use of government to equalize the income distribution is not the same as opposing the use of government to help the poor. It is possible to favor efforts to assist the truly needy while opposing policies that equalize positions among the nonpoor part of the population, and I am far from the first economist (or noneconomist, for that matter) to take this position. [Browning, $(1989$, p. 826)]
\end{abstract}

\section{Introduction}

In recent years, economists with differing views on many income distribution issues have begun to call for a public policy aimed at reducing poverty, rather than income inequality perse. Studies of variations in income inequality among regions have appeared in economics journals for several decades, ${ }^{1}$ but less work has been devoted to regional poverty measurement. This paper brings together recent theoretical and statistical advances in poverty measurement and develops a methodology for studying variations in poverty across small regions using readily available data from the Census Bureau.

To illustrate the methodology, we examine subregions of North Carolina, a state with considerable variation in poverty among its major subregions and counties. We find that regional poverty rankings differ substantially from income inequality rankings. Therefore, a public policy which seeks to alleviate absolute economic misery cannot use inequality measures as a guide. Tools specifically designed to identify those regions with the greatest poverty are required.

\footnotetext{
-Assistant Professors, Department of Economics, East Carolina University. The authors wish to thank Evan Anderson of the North Carolina State Data Center for assistance in obtaining the data. Scott Wallace assisted with the maps of North Carolina. John Formby made valuable comments on the manuscript.
}

The measurement of poverty requires that we address three distinct issues. First, any poverty measure necessarily contains ethical judgments about how poverty should be measured. Since our primary objective is to provide ordinal rankings of poverty, we base our study on the judgment that poverty decreases as incomes increase. Second, poverty rankings can be sensitive to the poverty line chosen. We use a methodology suggested by Foster and Shorrocks (1988), which generates poverty rankings using a flexible poverty line. Third, summary measures of poverty (and inequality) are of ten based on sample data and hence are subject to sampling variability. We address this issue by employing statistical tests for differences in income distributions developed by Beach and Davidson (1983), Bishop (1987), and Bishop, Formby, and Thistle (1989).

The data set for this study is a five percent random sample of North Carolina households from the 1980 Census. Two levels of substate regions can be identified in the data set: the three major subregions (Mountain, Piedmont, and Coastal Plain) of North Carolina, and the Census county groups within the state. The data set does not permit us to identify all counties within the region individually. ${ }^{2}$ The study focuses on the county groups in the Coastal Plain, the poorest of the three major subregions.

The paper proceeds as follows. Section II presents the methodology for generating regional poverty rankings based on sample data. Section III provides the North Carolina regional poverty rankings and contrasts them to rankings based on Gini coefficients and population mean incomes. The final section offers some concluding remarks.

\section{Methodology}

\section{Poverty Rankings}

Dalton (1920), Atkinson (1970, 1987), and others have shown that all inequality and poverty rankings require value judgments. We base our analysis on the judgment that poverty declines if the incomes of the poor increase. Foster and Shorrocks (1988) have shown that this value judgment permits us to generate poverty rankings from truncated order functions. A truncated order function is simply an income vector, $\left(\mathrm{y}_{1}, \mathrm{y}_{2}, \ldots, \mathrm{y}_{\mathrm{N}}\right)$, ordered from lowest to highest and truncated at the poverty cut-off. As in comparisons of income inequality with Lorenz curves, 
order functions may cross. Ordinal poverty rankings can only be constructed when the two truncated order functions do not cross below the poverty cut-off. ${ }^{3}$

This approach, like all attempts to measure poverty, faces the problem that poverty rankings may be sensitive to the location of the poverty cut-off separating the poor and the nonpoor. In particular, contradictory poverty rankings may be obtained when the order function is truncated at different poverty cut-offs. Foster and Shorrocks (1988) propose that we examine a range of poverty lines to check the stability of the rankings. If a poverty ranking is independent of the location of the poverty line within this range, the ranking is considered unambiguous. Otherwise, the poverty comparison is inconclusive.

Figure 1 illustrates several results thatplay an important role in the approach to poverty measurement used in this paper. First of all, it shows that choosing a poverty income line on the vertical axis is equivalent to limiting the poverty population to some percentage of the total population on the horizontal axis. For instance, if the poverty income line in Figure 1 is set at $C$, it follows that the poverty population is limited to the bottom $p_{c}$ percent of the population.

We recognize that the choice of a poverty income line (C) or a poverty population $\left(p_{c}\right)$ is somewhat arbitrary, and that poverty rankings can be sensitive to this choice. However, if we can establish a generous upper bound for the poverty line (or population) and generate identical poverty rankings for alternative poverty lines (or populations) below this upper bound, then the poverty rankings are unambiguous.

Returning to Figure 1, compare the truncated order functions $R(X 1)$ and $R(X 2)$ for two hypothetical regions. Since $R(X 1)$ lies everywhere below $R(X 2)$, we can conclude that poverty is more severe in region 1 than in region 2 , and justify that conclusion in two ways. First, choose any income on the vertical axis in Figure 1 as the poverty line, and observe that a larger percentage of the population in region 1 has incomes below this poverty line. Alternatively, choose any percentage of the population on the horizontal axis to represent the poor, and observe that the

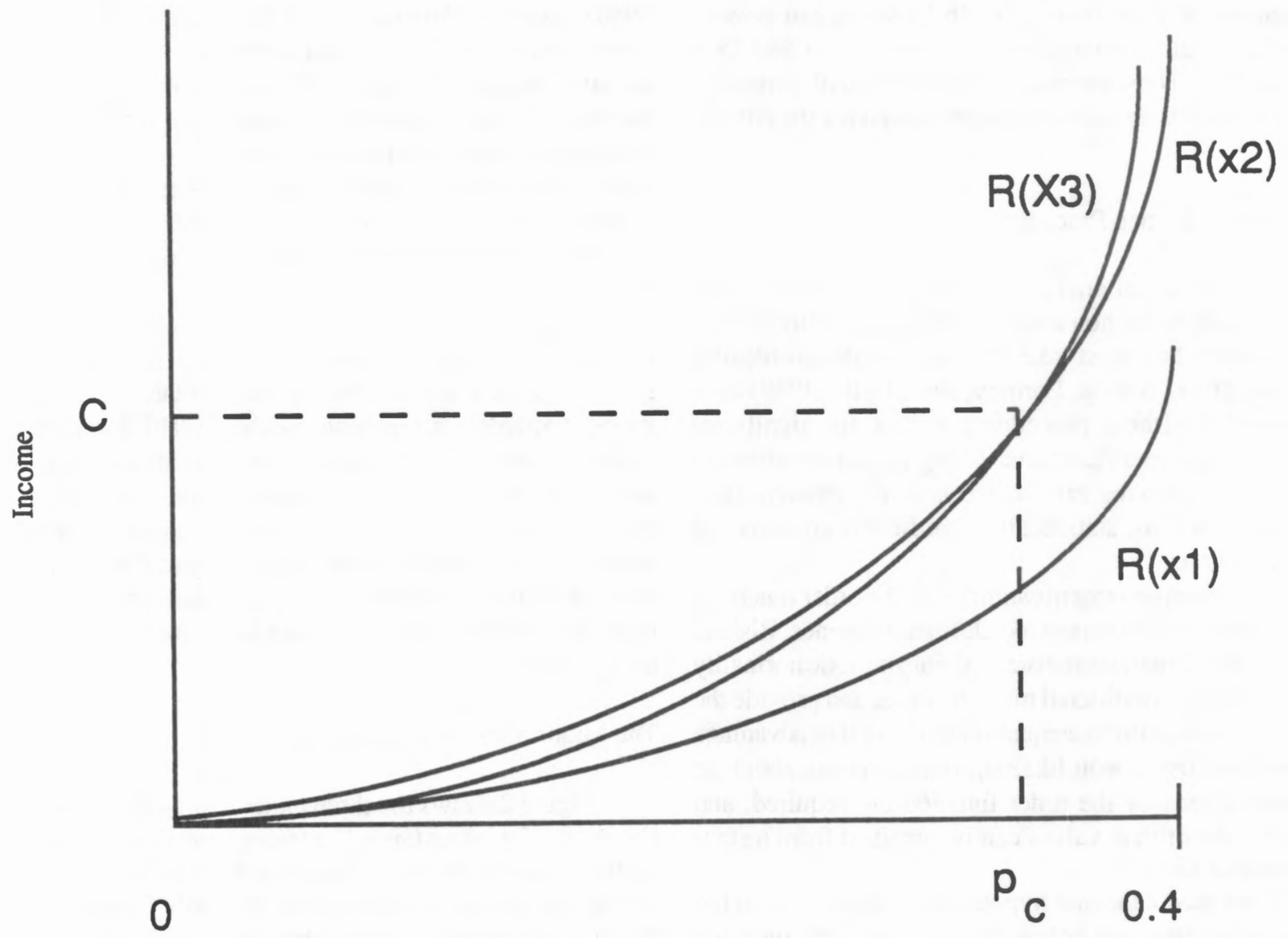

Population Percentiles

Figure One. Hypothetical Order Functions for Three Income Distributions (X1, X2, and x3) 
incomes of the households within this poverty population are smaller in region 1. Provided that R(X1) and R(X2) do not intersect, the relative poverty rankings will remain the same regardless of the location of the poverty cut-off.

Not all comparisons of poverty across regions will be unambiguous, as $R(X 2)$ and $R(X 3)$ in Figure 1 illustrate. If the poverty income line is set at or below $C$, the arguments from the previous paragraph can be used to show that poverty is more severe in region 3 than in region 2. However, if the upper bound for the poverty income line is above $\mathrm{C}$, conflicting poverty rankings can be obtained for different poverty lines, and the rankings must be considered ambiguous overall. Thus, Figure 1 shows that unambiguous poverty rankings are possible only when two truncated order functions do not intersect below the upper bound for the poverty cut-off.

In this paper we set an upper bound for the poverty cut-off at the thirtieth percentile in the distribution of households arranged by income. For the United States as a whole, estimates of the size of the poverty population typically range from ten to twenty percent of the total population. For the state of North Carolina, our poverty cut-off translates into a poverty income line of $\$ 8,975$ in 1979 dollars. Thus, we believe that the thirtieth percentile of households is a reasonable upper bound for the poverty cut-off.

\section{Statistical Inference Procedures}

The empirical analysis in this paper is based on a random sample of households. Meaningful inferences from sample data must take into account the problem of sampling error. Bishop, Formby, and Thistle (1989) have developed statistical procedures to test for significant differences in order functions. Using these procedures to account for sampling error corrects some apparent (i.e., numerical, but not statistically significant) crossings of order functions.

We obtain consistent estimates of the order functions using a vector of conditional (decile) mean incomes. Bishop, Formby, and Thistle demonstrate the asymptotic normality of the vector of conditional mean incomes and provide the variances on which to base equal-means tests. Theadvantage of this procedure is twofold: first, no assumptions about the parametric form of the order function are required, and secondly, the critical values can be obtained from a standard normal table.

If we accept the null hypothesis of equality at all the decile mean incomes below the poverty line, then the severity of poverty is equivalent in the two regions. Failure to accept the null hypothesis at any pair of decile means requires us to then differentiate between two cases: domi- nance and noncomparability. We find dominance of region $\mathrm{X}$ over region $\mathrm{Y}$ if region $\mathrm{X}$ has at least one significantly greater decile mean income and no decile mean significantly smaller. We find noncomparability when region $\mathrm{X}$ has at least one significantly greater decile mean income and at least one decile mean significantly smaller.

\section{Empirical Analysis}

To illustrate the methodology described above, we construct poverty rankings for subregions of North Carolina. We divide the state into three major subregions: the Mountains, Piedmont, and Coastal Plain. The poverty rankings for these regions use North Carolina as a whole, the South, and the United States as benchmarks. The Coastal Plain, the poorest of the three major subregions, is then partitioned into 1980 Census county groups. The poverty rankings for the county groups use the Coastal Plain as a whole and North Carolina as benchmarks.

The empirical analysis is based on a five percent random sample of North Carolina households from the 1980 Census of Population and Housing. The basic income measure is Census total household income, which includes wages and salaries, farm and nonfarm self-employment income, interest and dividends, Social Security payments, public assistance payments, and income from several other sources. Households reporting no income are included in the study. Households defined as institutional residences and households with no occupants are not included.

Unfortunately, Census household income does not include taxes or in-kind transfers. A more comprehensive measure of income would be desirable, but the Census has the most complete information readily available for substate regions. Implicitly, we assume that the distribution of taxes and in-kind transfers does not alter the relative poverty orderings based on the Census income definition. Since this paper generates ordinal poverty rankings, rather than cardinal measures of poverty (e.g., headcounts of the poor), the problems created by the Census income measure are not as severe.

\section{The Major Subregions of North Carolina}

Figure 2 shows the three major subregions of North Carolina: the Mountains, Piedmont, and Coastal Plain. ${ }^{4}$ Table 1 reports the mean incomes for the bottom three deciles of the major subregions of North Carolina, for North Carolina as a whole, the South, and the United States. Since the mean incomes are based on sample data, standard errors accompany each mean. The poverty income maximum in Table 1 is the highest income contained 
Constructing Poverty Rankings for State Subregions:

A Case Study of North Carolina

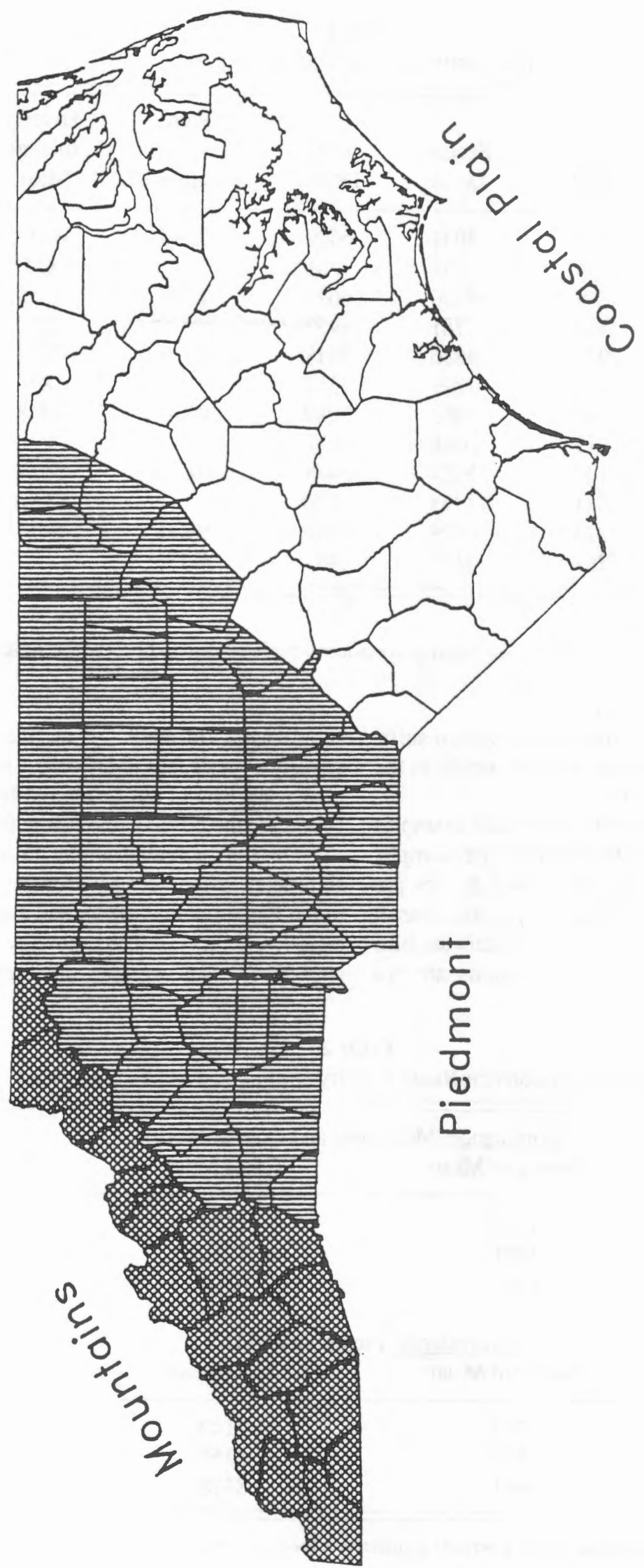


Table 1

Mean Incomes of the Poor by Region"

\begin{tabular}{lcccccc}
\hline \hline Region & $\begin{array}{c}\text { First } \\
\text { Decile }\end{array}$ & $\begin{array}{c}\text { Second } \\
\text { Decile }\end{array}$ & $\begin{array}{c}\text { Third } \\
\text { Decile }\end{array}$ & $\begin{array}{c}\text { Poverty } \\
\text { Income } \\
\text { Maximum }\end{array}$ & $\begin{array}{c}\text { Poverty } \\
\text { Income } \\
\text { Mean }\end{array}$ & $\begin{array}{c}\text { Sample } \\
\text { Size }\end{array}$ \\
\hline Coastal Plain & 1572 & 4031 & 6507 & 7740 & 4037 & 31382 \\
& $(32)$ & $(45)$ & $(58)$ & & $(131)$ & \\
Mountain & 1852 & 4250 & 6640 & 7790 & 4235 & 10169 \\
& $(55)$ & $(78)$ & $(95)$ & & $(221)$ & \\
North Carolina & 1974 & 4886 & 7618 & 8975 & 4826 & 104168 \\
& $(19)$ & $(29)$ & $(35)$ & & $(81)$ & \\
South & 1893 & 4963 & 7989 & 9510 & 4948 & 5174 \\
& $(91)$ & $(160)$ & $(204)$ & & $(453)$ & \\
United States & 2149 & 5354 & 8478 & 10005 & 5327 & 11696 \\
& $(58)$ & $(99)$ & $(115)$ & & $(270)$ & \multirow{2}{*}{ b } \\
Piedmont & 2273 & 5529 & 8440 & 9900 & 5414 & 62617 \\
& $(26)$ & $(40)$ & $(48)$ & $(113)$ & & \\
\hline \hline
\end{tabular}

"Standard errors are in parentheses.

The figures for the South and the United States are based on a random sample of Census households, which is described in detail in Bishop (1987).

in the third population decile. These figures seem sufficiently high to use the thirtieth income percentile as the upper bound for the poverty cut-off.

Table 2 illustrates the test procedure with examples of poverty dominanceand equivalence. In the firstexample, the mean incomes of the first and second deciles are significantly higher in the Mountains than in the Coastal Plain at the five percent significance level. Within the third decile, the mean incomes of the two regions are not significantly different. Thus, the Mountains have less poverty overall than the Coastal Plain. Notice that this conclusion would not be altered by relocating the upper bound for the poverty line below the thirtieth percentile.

In the second example in Table 2, there are no significant differences between any of the poverty deciles in the Piedmont and the United States at the five percent significance level. Thus, poverty in the two regions is equivalent. This example underscores the importance of

Table 2

Examples of Inference-Based Poverty Dominance and Equivalence

\begin{tabular}{cccc}
\hline \hline Decile & \multicolumn{2}{c}{ Dominance: Mountains and Coastal Plain } \\
Countains Mean & Coast Mean & Test Statistic* \\
\hline 1 & 1852 & 1572 & 4.43 \\
2 & 4031 & 4250 & 2.44 \\
3 & 6507 & 6304 & 0.87 \\
& & & \\
Decile & Equivalence: Piedmont and U.S. & Test Statistic* \\
& Piedmont Mean & U.S. Mean & 1.94 \\
2 & 2273 & 2149 & 1.64 \\
3 & 5529 & 5354 & -0.30 \\
\hline \hline
\end{tabular}

The critical value for the test statistic at the five percent significance level is 1.96 . 
Table 3

Pairwise Inference-Based Comparisons of Poverty*

\begin{tabular}{lcccccc}
\hline \hline & Coast & Mountains & Piedmont & NCarolina & South & U.S. \\
\hline Coast & $*$ & & & & & \\
Mountains & + & $*$ & & & & \\
Piedmont & + & + & $*$ & & & \\
North Carolina & + & + & - & $*$ & & \\
South & + & + & - & 0 & $*$ & $*$ \\
U.S. & + & + & 0 & + & + & $*$ \\
\hline \hline
\end{tabular}

"A "+" indicates that the row region has significantly less poverty than the column region (i.e., poverty dominance by the row region). A "-." indicates the converse. A " 0 " indicates that the row region and the column region have statistically equivalent poverty (i.e., poverty equivalence).

inference-based poverty rankings. A simple numerical comparison of these regions would lead to the erroneous conclusion that poverty is noncomparable, because the two order functions cross numerically.

Table 3 summarizes the results of all the possible pairwise regional tests. A " + " in Table 3 indicates that the row region has significantly less poverty than the column region. A "-" in Table 3 indicates that the row region has significantly more poverty than the column region. A " 0 " indicates that poverty in the two regions is statistically equivalent. For example, the first entry contains a " + " to indicate that there is less poverty in the Mountains than in the Coastal Plain. Similarly, the entry for the United States and the Piedmont is a " 0 " to indicate the equivalence of the two regions.

It is striking that none of the 15 pairwise comparisons in Table 3 yield a noncomparable outcome. Thus, we are able to construct a complete regional poverty ranking. The Mountains dominate the Coastal Plain, but are dominated by all the other regions. At the other extreme, the United

Table 4

County Group Definitions

County

Group Counties Included in Each County Group

\begin{tabular}{ll} 
A & Johnston, Lee \\
B & Nash, Wilson \\
C & Edgecombe, Halifax, Northampton \\
D & Beaufort, Bertie, Hertford, Martin, Pitt \\
E & Camden, Chowan, Currituck, Dare, Gates, Hyde, Pasquotank, Perquimans, Tyrell, Washington \\
F & Carteret, Craven, Jones, Pamlico \\
G & Onslow \\
H & Greene, Wayne \\
I & Duplin, Lenoir \\
J & New Hanover \\
K & Brunswick, Columbus, Pender \\
L & Bladen, Hoke, Robeson, Scotland \\
M & Cumberland \\
N & Harnett, Sampson \\
\hline
\end{tabular}

'Lee county is usually not included in the Coastal Plain, but observations from Johnston and Lee counties cannot be distinquished in the data set. Hence, either Johnston county must be excluded from the definition of the Coastal Plain or Lee county must be included. We chose the latter option. 
Table 5

Mean Incomes of the Poor by Census County Group*

\begin{tabular}{|c|c|c|c|c|c|c|}
\hline $\begin{array}{l}\text { County } \\
\text { Group }\end{array}$ & $\begin{array}{l}\text { First } \\
\text { Decile }\end{array}$ & $\begin{array}{l}\text { Second } \\
\text { Decile }\end{array}$ & $\begin{array}{l}\text { Third } \\
\text { Decile }\end{array}$ & $\begin{array}{c}\text { Poverty } \\
\text { Income } \\
\text { Maximum }\end{array}$ & $\begin{array}{l}\text { Poverty } \\
\text { Income } \\
\text { Mean }\end{array}$ & $\begin{array}{c}\text { Sample } \\
\text { Size }\end{array}$ \\
\hline A & $\begin{array}{l}1709 \\
(138)\end{array}$ & $\begin{array}{l}4090 \\
(171)\end{array}$ & $\begin{array}{l}6581 \\
(244)\end{array}$ & 7805 & $\begin{array}{l}4126 \\
(532)\end{array}$ & 1890 \\
\hline B & $\begin{array}{l}1800 \\
(109)\end{array}$ & $\begin{array}{l}4389 \\
(191)\end{array}$ & $\begin{array}{l}7107 \\
(219)\end{array}$ & 8300 & $\begin{array}{l}4432 \\
(511)\end{array}$ & 2261 \\
\hline C & $\begin{array}{l}1243 \\
(122)\end{array}$ & $\begin{array}{l}3380 \\
(128)\end{array}$ & $\begin{array}{l}5363 \\
(195)\end{array}$ & 6505 & $\begin{array}{l}3329 \\
(426)\end{array}$ & 2195 \\
\hline D & $\begin{array}{l}1262 \\
(96)\end{array}$ & $\begin{array}{l}3364 \\
(110)\end{array}$ & $\begin{array}{l}5612 \\
(216)\end{array}$ & 6865 & $\begin{array}{l}3413 \\
(517)\end{array}$ & 3377 \\
\hline $\mathrm{E}$ & $\begin{array}{l}1617 \\
(122)\end{array}$ & $\begin{array}{l}4069 \\
(190)\end{array}$ & $\begin{array}{l}6627 \\
(216)\end{array}$ & 7755 & $\begin{array}{l}4104 \\
(517)\end{array}$ & 1991 \\
\hline $\mathbf{F}$ & $\begin{array}{l}1709 \\
(106)\end{array}$ & $\begin{array}{l}4223 \\
(195)\end{array}$ & $\begin{array}{l}6868 \\
(194)\end{array}$ & 7965 & $\begin{array}{l}4267 \\
(490)\end{array}$ & 2274 \\
\hline $\mathbf{G}$ & $\begin{array}{l}2049 \\
(186)\end{array}$ & $\begin{array}{l}5471 \\
(207)\end{array}$ & $\begin{array}{l}7381 \\
(199)\end{array}$ & 8370 & $\begin{array}{l}4967 \\
(580)\end{array}$ & 1521 \\
\hline $\mathrm{H}$ & $\begin{array}{l}1826 \\
(121)\end{array}$ & $\begin{array}{l}4327 \\
(175)\end{array}$ & $\begin{array}{l}6667 \\
(248)\end{array}$ & 8005 & $\begin{array}{l}4273 \\
(532)\end{array}$ & 1881 \\
\hline I & $\begin{array}{l}1524 \\
(135)\end{array}$ & $\begin{array}{l}3684 \\
(178)\end{array}$ & $\begin{array}{l}6018 \\
(225)\end{array}$ & 7170 & $\begin{array}{l}3742 \\
(515)\end{array}$ & 1741 \\
\hline $\mathbf{J}$ & $\begin{array}{l}1939 \\
(134)\end{array}$ & $\begin{array}{l}4602 \\
(195)\end{array}$ & $\begin{array}{l}7282 \\
(269)\end{array}$ & 8700 & $\begin{array}{l}4608 \\
(584)\end{array}$ & 1896 \\
\hline $\mathbf{K}$ & $\begin{array}{l}1403 \\
(121)\end{array}$ & $\begin{array}{l}3406 \\
(156)\end{array}$ & $\begin{array}{l}5798 \\
(243)\end{array}$ & 7040 & $\begin{array}{l}3536 \\
(502)\end{array}$ & 1855 \\
\hline L & $\begin{array}{l}1574 \\
(92)\end{array}$ & $\begin{array}{l}3766 \\
(141)\end{array}$ & $\begin{array}{l}6138 \\
(173)\end{array}$ & 7260 & $\begin{array}{l}3826 \\
(398)\end{array}$ & 2892 \\
\hline $\mathbf{M}$ & $\begin{array}{l}1437 \\
(136)\end{array}$ & $\begin{array}{l}4265 \\
(236)\end{array}$ & $\begin{array}{l}6616 \\
(226)\end{array}$ & 7735 & $\begin{array}{l}4106 \\
(588)\end{array}$ & 1548 \\
\hline $\mathbf{N}$ & $\begin{array}{l}1923 \\
(161)\end{array}$ & $\begin{array}{l}5633 \\
(224)\end{array}$ & $\begin{array}{l}8340 \\
(219)\end{array}$ & 9580 & $\begin{array}{l}5299 \\
(593)\end{array}$ & 2212 \\
\hline
\end{tabular}

Standard errors are in parentheses.

States and the Piedmont dominate all other regions. Also, poverty in North Carolina as a whole is equivalent to poverty in the South.

The Census County Groups in the Coastal Plain

The significant differences in poverty among the major subregions of North Carolina lead us to consider variations in poverty among the Census county groups. We focus on the county groups in the poorest of the three regions, the Coastal Plain. To facilitate exposition, the county groups in the Coastal Plain are assigned the letters A through $\mathrm{N}$ (see Table 4). Table 5 provides the mean incomes and standard errors for the poverty deciles in these fourteen county groups.
The point estimates themselves would suggest numerous instances (e.g., $\mathrm{L}$ and $\mathrm{M}$ ) in which the poverty comparisons are inconclusive due to sensitivity to the location of the poverty line. However, statistical tests at the five percent significance level eliminate any ambiguity in the 91 pairwise comparisons. Thus, the poverty rankings do not depend on the location of the poverty line within the bottom three deciles. This result allows us to summarize the poverty rankings using the cumulative mean incomes of the three poverty deciles.

Table 6 ranks the county groups in the Coastal Plain from lowest to highest by the mean income of the poor, by a Gini index of equality, and by the mean income of the total population. 5 Each column in Table 6 is normalized by setting the mean for North Carolina to 1.00 . A single 
Table 6

Comparison of Poverty, Income Equality, and Mean Income Rankings

(2)

(4)

(6)

Population

\begin{tabular}{|c|c|c|c|c|c|}
\hline $\begin{array}{l}\text { County } \\
\text { Group }\end{array}$ & Poverty & $\begin{array}{l}\text { County } \\
\text { Group }\end{array}$ & $\begin{array}{l}\text { Income } \\
\text { Equality }^{b}\end{array}$ & $\begin{array}{l}\text { County } \\
\text { Group }\end{array}$ & $\begin{array}{c}\text { Mean } \\
\text { Income }^{c}\end{array}$ \\
\hline C & .68 & D & .934 & $\mathbf{N}$ & .81 \\
\hline D & .71 & C & .941 & $\mathbf{L}$ & .85 \\
\hline $\mathbf{K}$ & .73 & $\mathbf{K}$ & .945 & $\mathrm{C}$ & .85 \\
\hline---- & ----- & I & .958 & I & .86 \\
\hline I & $.78^{* *}$ & ----- & ----- & $\mathbf{K}$ & .86 \\
\hline $\mathrm{L}$ & $.79 * *$ & Coast & .976 & ----- & --- \\
\hline $\mathbf{N}$ & $.80 * *$ & A & $.978 * *$ & G & $.88 * *$ \\
\hline Coast & .83 & J & $.979 * *$ & D & $.88^{* *}$ \\
\hline E & $.84 * *$ & ----- & $--ー--$ & E & $.89 * *$ \\
\hline A & $.85^{* *}$ & B & $.982 *$ & Mountains & $.89 * *$ \\
\hline---- & ----- & F & $.982^{*}$ & Coast & .90 \\
\hline Mountains & .88 & L & $.983^{*}$ & $\mathbf{H}$ & $.91 * *$ \\
\hline F & .88 & Mountains & $.992 *$ & $\mathbf{A}$ & $.92 * *$ \\
\hline $\mathrm{H}$ & .88 & H & $.992 *$ & ----- & --- \\
\hline B & .91 & $\mathbf{N}$ & $.992 *$ & F & .93 \\
\hline J & $.95^{*}$ & E & $.994^{*}$ & $\mathbf{M}$ & .95 \\
\hline N Carolina & 1.00 & N Carolina & 1.000 & B & $.97^{*}$ \\
\hline G & $1.05^{*}$ & Piedmont & $1.018^{*}$ & N Carolina & 1.00 \\
\hline $\mathbf{M}$ & 1.11 & G & 1.037 & $\mathrm{~J}$ & 1.05 \\
\hline Piedmont & 1.12 & $\mathbf{M}$ & 1.058 & Piedmont & 1.10 \\
\hline
\end{tabular}

Equivalent to North Carolina at the 5 percent significance level.

"Equivalent to the Coastal Plain at the 5 percent significance level.

Themeasure of poverty is PovMean(X)/PovMean(NC), where PovMean $(X)$ is the cumulative mean income of the poor for any county group $\mathrm{X}$ and PovMean(NC) is the cumulative mean income of the poor for North Carolina (\$4826).

The measure of income equality is [1 - Gini(X)]/[1 - Gini(NC)], where $\operatorname{Gini}(X)$ is the Gini coefficient for any county group $X$ and Gini(NC) is the Gini coefficient for North Carolina (0.391).

Themeasure of population mean income is $\mathrm{Mean}(\mathrm{X}) / \mathrm{Mean}(\mathrm{NC})$, where $\mathrm{Mean}(\mathrm{X})$ is the population mean income for any county group $\mathrm{X}$ and Mean(NC) is the population mean income for North Carolina $(\$ 16,479)$.

asterisk indicates that a county group is not significantly different from the state. Two asterisks indicate that a county group is not significantly different from the Coastal Plain. The dashed lines in Table 6 separate the county groups in each column into three categories: below average for the Coastal Plain, average for the Coastal Plain, and above average for the Coastal Plain.

Figure 3 maps the county groups in the Coastal Plain according to these three categories. The map illustrates the heterogeneity of the Coastal Plain and identifies two subregions with poverty rankings significantly below average for the Coastal Plain. A public policy aimed specifically at reducing poverty (as opposed to inequality per se) would have to focus on these pockets of poverty.
The results in Table 6 provide evidence that neither the Gini equality rankings nor the population mean income rankings are good substitutes for poverty rankings. Consider county group $\mathbf{N}$ for example, which has a poverty ranking equivalent to the Coastal Plain, but significantly more equal incomes and a significantly lower population mean income. Consider county group $\mathrm{G}$ as well, which has a poverty ranking equivalent to the state, but significantly more equal incomes and a significantly lower population mean income. County group J has a significantly greater population mean income and significantly less equal incomes than the State, but an equivalent poverty ranking. Along with other comparisons that could be pointed out from Table 6, these findings suggest that neither the Gini 

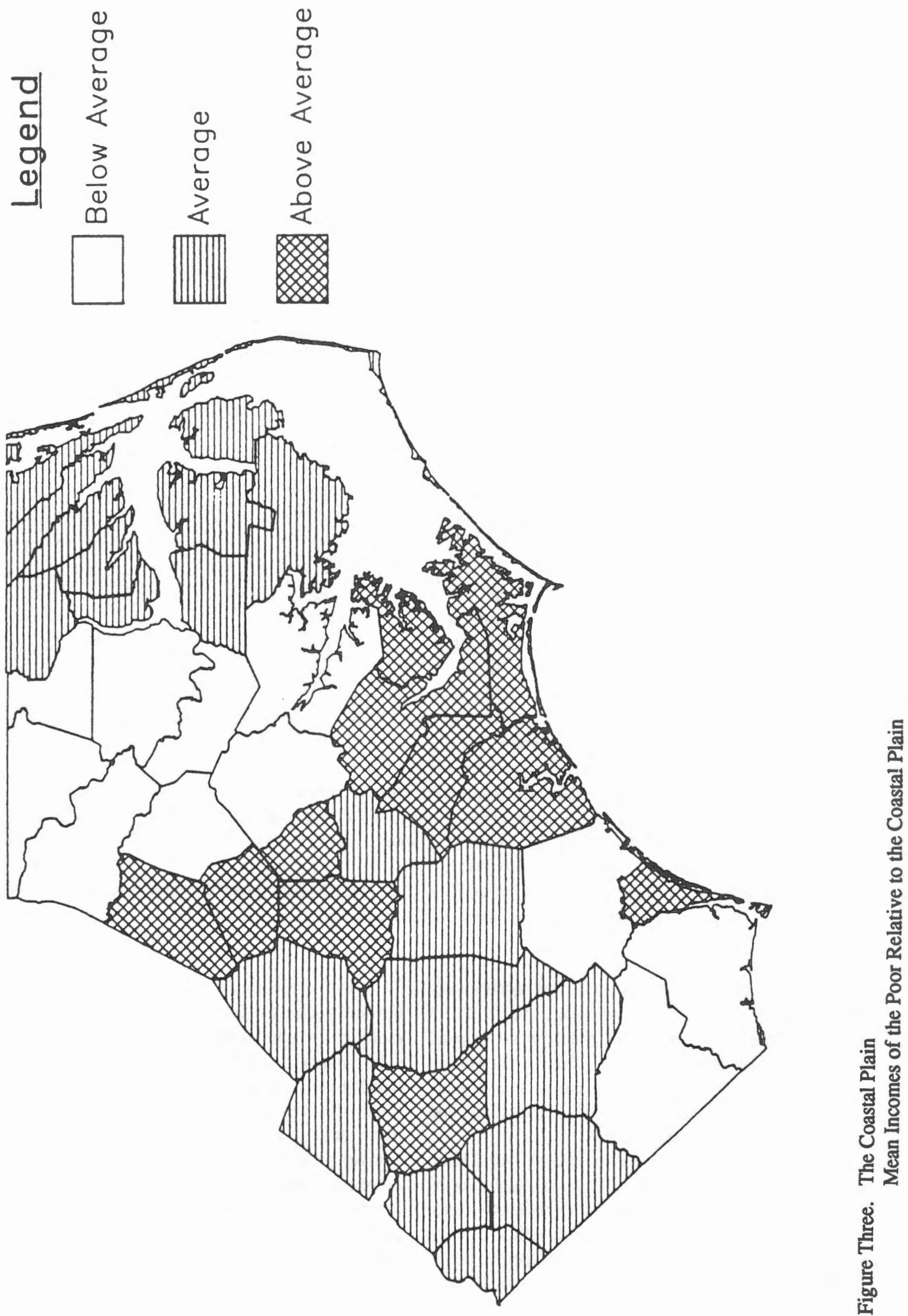
equality rankings nor the population mean income rankings provide satisfactory substitutes for poverty rankings.

\section{Conclusions}

We present a methodology for studying variations in poverty across small regions using readily available data from the Census Bureau. This methodology checks for ambiguity in poverty rankings due to variations in the location of the poverty line. The regional poverty rankings obtained here are not sensitive to the location of the poverty line within a reasonable range. This conclusion is based on recently developed statistical inference procedures which test for significant differences in poverty rankings among regions.

The methodology is applied to major state subregions and Census county groups in North Carolina, which shows considerable variations in poverty among its regions. The regional poverty rankings for North Carolina are compared to rankings by income equality and population mean incomes. We find important differences among these rankings. This finding suggests that a public policy that seeks to alleviate absolute economic misery cannot use inequality measures as a guide. Instead, tools specifically designed to identify regions with the greatest poverty are required.

\section{Notes}

'Recent extensions of this line of research include Amos (1986) and Maxwell and Peter (1988), which contain references to the previous literature.

2In sparsely populated regions, as parts of the Coastal Plain are, the Census Bureau does not identify counties individually in public use microdata to ensure the anonymity of household records.

3f course, with stronger value judgments, unambiguous poverty comparisons can be obtained. However, stronger value judgments will command less general agreement.

4The boundaries for the major subregions are taken from Clay,
Orr, and Stuart (1975). The only exception is Lee county, which is included in the Coastal Plain because the Census data combines it with Johnston county.

'Formulas for the lower-bound Gini coefficients and their variances are given by Beach and Davidson (1983).

\section{References}

Amos, Jr., Orley M. "Substate and SMSA Personal Income Inequality and Regional Development." Review of Regional Studies. 16 (1986). 23-30.

Atkinson, Anthony B. "On the Measurement of Inequality." Journal of Economic Theory. 22 (1970). 244-263.

Atkinson, Anthony B. "On the Measurement of Poverty." Econometrica. 5 (1987). 749-764.

Beach, C. M. and Davidson, R. "Distribution-free Statistical Inferences with Lorenz Curves and Income Shares." Review of Economic Studies. 50 (1983). 723-35.

Bishop, John A. "Statistical Inference with Lorenz and Generalized Lorenz Curves: An Interstate and Inter-Temporal Comparison." Ph.D. Dissertation, University of Alabama, 1987.

Bishop, J. A., Formby, J. P. and Thistle, P. D. "Statistical Inference, Income Distribution, and Social Welfare."In D. J. Slottje (ed.). Research in Income Inequality. Vol. 1. Greenwich, CT: JAI Press, 1989. 49-82.

Browning, Edgar K. "Inequality and Poverty." Southern Economic Journal. 55 (1989). 819-830.

Clay, James W., Orr, Douglas M., and Stuart, Alfred W. (eds.). North Carolina Atlas: Portrait of a Changing Southern State. Chapel Hill: The University of North Carolina Press, 1975.

Dalton, Hugh. "The Measurement of the Inequality of Incomes." Economic Journal. 30 (1920). 348-61.

Fields, Gary S. Poverty, Inequality, and Development. Cambridge: Cambridge University Press, 1980.

Foster, J. E., and Shorrocks, A. F. "Poverty Orderings." Econometrica. 56 (1988). 1973-77.

Maxwell, Philip, and Peter, Matthew. "Income Inequality in Small Regions: A Study of Australian Statistical Divisions." Review of Regional Studies. 18 (1988). 19-27. 